\title{
UJI BEBERAPA KONSENTRASI EKSTRAK TEPUNG DAUN SRIKAYA UNTUK MENGENDALIKAN Aphis gossypii Glover PADA TANAMAN CABAI
}

\author{
(Test of Some Concentrations of Srikaya Leaf Flour Extract to Control Aphis gossypii Glover Pests \\ on Chili Pepper)
}

HAFIZ FAUZANA* ${ }^{* 1}$ RIZKY AULINA HARAHAP ${ }^{1}$

Jurusan Agroteknologi, Fakultas Pertanian, Universitas Riau

Kampus Bina Widya Km 12,5 Simpang Baru, Pekanbaru, 28293

*Email : fauzana_hafiz@yahoo.co.id

\begin{abstract}
Aphis gossypii Glover is the main pest that attacks chili pepper. Control efforts that are often carried out are by using synthetic insecticides. Safe pest control is the use of botanical insecticides. Srikaya is a plant that can be used as a botanical insecticide. The purpose of this study was to obtain an effective concentration of srikaya leaf flour extract against $A$. gossypii mortality. This research was conducted at the Plant Pest Laboratory of the Faculty of Agriculture, Riau University from March to July 2019. The study was conducted experimentally using a completely randomized design (CRD) with 6 treatments and 4 replications. The treatments were extracts of srikaya leaf powder with the following concentrations: Srikaya flour with a concentration of $0 \mathrm{~g} . \mathrm{I}^{-1}$ water, $20 \mathrm{~g} . \mathrm{I}^{-1}$ water, $40 \mathrm{~g} . \mathrm{l}^{-1}$ water,

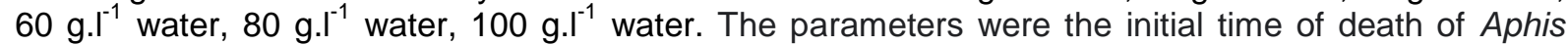
gossypii, Lethal time 50 ( $\left.\mathrm{LT}_{50}\right)$, daily mortality, total mortality, Lethal concentration 50 ( $\left.\mathrm{LC}_{50}\right)$, temperature and humidity. The results of this study indicated that the application of the extract of srikaya leaf flour (Annona squamosa L.) on concentration of $40 \mathrm{gl}-1$ srikaya leaf flour estract was the most effective concentration to control A. gossypii which caused total mortality of $82.5 \%$ with LC50 of $1.37 \%$ or equivalent to $13.7 \mathrm{gl}-1$, and the right concentration to kill. $95 \%$ of pests is $6.37 \%$ or equivalent to $63.7 \mathrm{gl}-1$.
\end{abstract}

Keywords: Annona squamosa, Aphis gossypii, Botanical Insectiside, Capsicum annum, Concentration

\section{PENDAHULUAN}

$\begin{array}{lll}\text { Cabai (Capsicum annum L.) } & \end{array}$ mempunyai nilai ekonomis yang tinggi, sehingga ditanam hampir di seluruh wilayah Indonesia termasuk di Provinsi Riau. Berdasarkan data dari Badan Pusat Statistik (2018) melaporkan bahwa produksi tanaman cabai pada tahun 2016 sebesar 12.003 ton dengan luas lahan sebesar 1.775 ha dan pada tahun 2017 sebesar 15.813 ton dengan luas lahan sebesar 2.236 ha. Peningkatan luas lahan tanaman cabai menyebabkan peningkatan terhadap serangan hama. Aphis gossypii merupakan salah satu hama yang menyerang tanaman cabai.

Kutu daun $A$. gossypii merupakan hama utama yang menyerang daun cabai. Kutu ini menyebabkan kerusakan dengan cara menghisap cairan sel daun yang mengakibatkan daun tumbuh tidak normal. Kutu $A$. gossypii juga sebagai vektor penyebab penyakit yang disebabkan oleh virus (Pracaya, 2007). Kerugian yang diakibatkan oleh $A$. gossypii sebagai hama berkisar $6-25 \%$, sedangkan sebagai vektor virus penyebab penyakit mencapai lebih dari 90\% (Herlinda et al, 2009).

Upaya pengendalian yang telah dilakukan untuk $A$. gossypii adalah insektisida sintetis. Pemakaian insektisida sintetis dapat meninggalkan efek residu bahan kimia pada hasil pertanian. Aplikasi insektisida sintetis yang terus menerus menyebabkan terjadinya resistensi hama, resurgensi hama, timbulnya hama sekunder, matinya musuh alami dan pencemaran lingkungan (Pracaya, 2007). Oleh karena itu, diupayakan teknologi lain untuk mengendalikan hama secara aman dan efektif, yakni penggunaan insektisida nabati (Novizan, 2002). Keunggulan insektisida nabati dibandingkan insektisida sintetis adalah ramah lingkungan, ekonomis, tidak membahayakan bagi manusia, dan tidak menimbulkan residu pada tanaman (Martono, 2004).

Srikaya (Annona squamosa) merupakan salah satu jenis tanaman yang dapat digunakan sebagai insektisida nabati. Tanamana srikaya mengandung senyawa aktif utama yang bersifat antifeedant dan insektisida adalah asimisin dan squamosin (golongan asetogenin). Tumbuhan dari 
keluarga Annonaceae mengandung alkaloid, karbohidrat, lemak (42 - 45\%), asam amino, protein, polifenol, minyak atsiri, terpen, dan senyawa yang bersifat bioaktif dari kelompok tumbuhan Annonaceae dikenal dengan nama asetogenin yang dapat bekerja sebagai racun kontak (Kardinan, 2002)

Menurut hasil penelitian Sinaga (2010) menunjukkan bahwa perlakuan serbuk biji srikaya yang mengandung senyawa squamosin dengan dosis $2,5 \mathrm{~g}$. $100^{-1} \mathrm{~g}$ kacang hijau menyebabkan mortalitas Callosobruchus chinensis mencapai $100 \%$. Hal ini sesuai dengan pendapat Dadang dan Prijono (2008) insektisida dikatakan efektif apabila mampu mematikan serangga hama besar atau sama dengan $80 \%$.

Penelitian ini bertujuan untuk mendapatkan konsentrasi ekstrak tepung daun srikaya yang efektif dalam mengendalikan $A$. gossypii pada cabai.

\section{BAHAN DAN METODE}

Penelitian ini telah dilaksanakan di Laboratorium Hama Tumbuhan Fakultas Pertanian Universitas Riau Kampus Bina Widya km 12,5 Pekanbaru. Penelitian dilaksanakan dari bulan Juli sampai September 2019.

Penelitian ini dilakukan secara eksperimen dengan menggunakan Rancangan Acak Lengkap (RAL) dengan 6 perlakuan dan 4 kali ulangan sehingga diperoleh 24 unit percobaan. Perlakuan yang diberikan adalah beberapa konsentrasi ekstrak tepung daun srikaya yaitu $0{\mathrm{~g} . \mathrm{I}^{-1}}^{-1}$ air, $20{\mathrm{~g} . \mathrm{I}^{-1}}^{-1}$ air, $40 \mathrm{~g} . \mathrm{l}^{-1}$ air, $60 \mathrm{~g} . \mathrm{I}^{-1}$ air, $80 \mathrm{~g} . \mathrm{I}^{-1}$ air, $100 \mathrm{~g} . \mathrm{l}^{-1}$ air.

Penelitian dimulai dengan menanam tanaman perbanyakan dan perlakuan. Benih cabai yang digunakan adalah varietas copay. Jumlah tanaman perbanyakan yang ditanaman sebanyak 20 tanaman, sedangkan jumlah tanaman perlakuan yang ditanam sebanyak 24 tanaman. Tanaman perbanyakan dan perlakuan dipelihara tanpa menggunakan pestisida sintetis.

Kutu daun Aphis gossypii dilakukan perbanyakan dengan cara mengambil imagonya dari UPT Fakultas Pertanian Universitas Riau. Imago A. gossypii ke dalam stoples secara langsung dengan memotong bagian tanaman yang telah terserang. Imago A. gossypii yang telah diambil kemudian dipindahkan ke tanaman perbanyakan sebanyak 10 ekor per tanaman. Imago turunan F1 kemudian yang merupakan generasi 0 akan dipindahkan ke tanaman perlakuan.
Tanaman perlakuan diberi sungkup untuk menjaga $A$. gossypii yang diinfestasikan terlindungi dari musuh alami dan mencegah keluarnya hama. Sungkup berukuran tinggi 50 $\mathrm{cm}$ dengan diameter $18 \mathrm{~cm}$. Ventilasi udara dibuat dengan diameter $15 \mathrm{~cm}$.

Daun srikaya diambil dari Kecamatan Bukit Batu Kabupaten Bengkalis. Daun srikaya yang digunakan adalah daun tua. Daun dikeringanginkan selama seminggu. Daun dipotong dengan ukuran $1 \mathrm{~cm}$ kemudian diblender hingga menjadi tepung dan disaring. Tepung ditimbang dengan ukuran masing masing yaitu 0 g, 20 g, 40 g, 60 g, 80 g, $100 \mathrm{~g}$ sesuai dengan perlakuan. Setiap perlakuan ditambahkan $1000 \mathrm{ml}$, kemudian larutan diaduk dan ditambahkan sabun krim sebanyak $1 \mathrm{~g}$. Larutan diaduk hingga homogen, dan didiamkan selama 3 jam. Setelah itu disaring menggunakan kain kasa untuk mendapatkan ekstrak daun srikaya.

Imago A. gossypii diinfestasikan sebanyak 2 imago(generasi 1)/tanaman. Imago yang telah diinfestasikan akan meletakkan nimfa pada tanaman perlakuan. Nimfa $A$. gossypii yang digunakan adalah instar VI yang telah berumur 6 hari sebanyak 10 nimfa(generasi 2)/tanaman dengan ciri kepala bewarna kehitaman serta abdomen berwarna hijau kekuningan.

Aplikasi perlakuan dilakukan setelah nimfa A. gossypii berumur 6 hari. Penyemprotan dilakukan dengan menggunakan botol spray volume $100 \mathrm{ml}$ dengan volume semprot $5 \mathrm{ml}$ pertanaman. Waktu penyemprotan dimulai pukul 07.00 WIB. Penyemprotan dilakukan dengan membasahi seluruh bagian tanaman secara merata dari pucuk cabai, bawah daun dan seluruh bagian tanaman.

Parameter pengamatan yang diamati yaitu perubahan awal kematian Aphis gossypii, Lethal time $50\left(\mathrm{LT}_{50}\right)$, persentase mortalitas harian, Lethal concentration $\left(\mathrm{LC}_{50}\right)$, persentase mortaltas total.

\section{HASIL DAN PEMBAHASAN}

\section{Waktu Awal Kematian}

Hasil sidik ragam menunjukkan bahwa perlakuan beberapa konsentrasi ekstrak tepung daun srikaya terhadap waktu awal kematian $A$. gossypii. Hasil rata-rata waktu awal kematian $A$. gossypii setelah dilakukan uji DNMRT pada taraf $5 \%$ dapat dilihat pada Tabel 1. Tabel 1 menunjukkan bahwa perlakuan beberapa konsentrasi ekstrak tepung daun srikaya berpengaruh nyata terhadap waktu awal kematian A.gossypii. Kisaran waktu awal kematian A.gossypii terjadi antara 1,75-72 jam setelah aplikasi. 
Hasil penelitian menunjukkan bahwa perlakuan ekstrak tepung daun srikaya

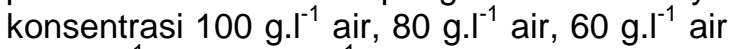

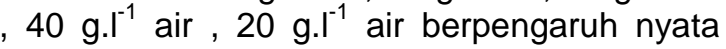
terhadap antar perlakuan dengan waktu masing-masing 1,75 jam, 3 jam, 4,75 jam, 6,75 jam, dan 9,75 jam. Pemberian perlakuan dengan konsentrasi 0 g..$^{-1}$ air ekstrak daun srikaya tidak terjadi kematian A.gossypii. Hal ini disebabkan karena pada perlakuan tersebut tidak diberi ekstrak tepung daun srikaya sehingga hama A.gossypii tidak mengalami kematian pada akhir pengamatan (72 jam).

Tabel 1. Waktu awal kematian A. gossypii setelah pemberian beberapa konsentrasi ekstrak tepung daun srikaya

\begin{tabular}{cc}
\hline $\begin{array}{c}\text { Konsentrasi ekstrak tepung daun srikaya } \\
\left(\text { g. } .^{-1} \text { air) }\right.\end{array}$ & $\begin{array}{c}\text { Waktu awal kematian } \\
\text { (jam) }\end{array}$ \\
\hline 0 & $72,00^{\mathrm{a}}$ \\
20 & $9,75^{\mathrm{b}}$ \\
60 & $6,75^{\mathrm{c}}$ \\
80 & $4,75^{\mathrm{a}}$ \\
100 & $3,00^{\mathrm{e}}$ \\
\hline
\end{tabular}

Keterangan : Angka-angka pada lajur yang diikuti oleh huruf kecil yang tidak sama berbeda nyata menurut uji DNMRT pada taraf $5 \%$ setelah ditransformasikan $\sqrt{ } y+0,5$.

Perlakuan konsentrasi ekstrak tepung daun srikaya $100{\mathrm{~g} . \mathrm{I}^{-1}}$ air menunjukkan waktu awal kematian A.gossypii pada 1,75 jam setelah aplikasi dan berbeda nyata dengan perlakuan lainnya. Hal ini membuktikan bahwa semakin tinggi tingkat kepekatan suatu senyawa kimia, maka semakin banyak senyawa aktif yang dikandungnya dan semakin cepat daya bunuhnya. Pendapat ini didukung oleh Dewi (2010) yang menyatakan bahwa konsentrasi ekstrak yang lebih tinggi akan menimbulkan daya bunuh hama yang lebih cepat. Hal ini memperlihatkan bahwa semakin tinggi ekstrak tepung daun srikaya (Annona squamosa L.) maka semakin cepat pula awal kematian kutu daun Aphis gossypii . Semakin tinggi konsentrasi maka senyawa squamosin pada daun srikaya akan semakin tinggi. Harbone 1979 dalam Nursal et al. (1997) menyatakan bahwa konsentrasi ekstrak yang lebih tinggi maka pengaruh yang ditimbulkan semakin tinggi pula, disamping itu daya kerja suatu senyawa sangat ditentukan oleh besarnya konsentrasi.

Srikaya mengandung senyawa alkaloida terutama squamosin yang dapat berfungsi sebagai racun perut dan racun kontak terutama untuk hama gudang dan Aphid (Departemen Pertanian, 1989). Racun perut masuk melalui alat mulut $A$. gossypii pada proses pengisapan cairan tanaman, sedangkan racun kontak masuk melalui dinding tubuh dan lubang alami yang terdapat pada $A$. gossypii tersebut. Hal ini diperkuat oleh (Ardiansyah, 2001) yang menyatakan bahwa selain melalui lapisan kutikula pada hama, mekanisme kerja suatu racun kontak juga dapat masuk ke dalam tubuh hama.
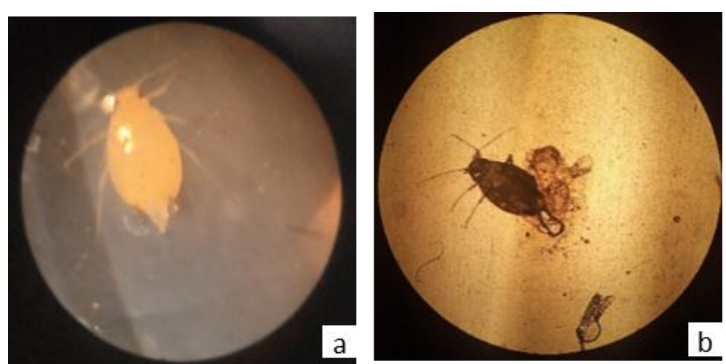

Gambar 1. Perubahan morfologi A.gossypii dengan perlakuan ekstrak tepung daun srikaya. (a) A. gossypii yang masih hidup berwarna kekuningan pada perlakuan 0 g. I $^{-1}$ air, (b) $A$. gossypii yang sudah mati berwarna cokelat (Dokumentasi penelitian, 2019).

Di dalam tubuh serangga, senyawa aktif yang terkandung di dalam insektisida nabati akan mengganggu kerja sistem syaraf dan sistem pencernaan serangga sehingga menyebabkan terganggu-nya aktivitas $A$. gossypii dan perlahan-lahan akan menyebabkan kematian (Zarkani, 2008). Hal ini ditandai dengan perubahan morfologi pada A.gossypii berupa terjadinya perubahan warna tubuh dari kuning menjadi kecoklatan yang berlanjut menjadi hitam (Gambar 1). Perubahan warna pada tubuh $A$. gossypii setelah aplikasi ekstrak tepung daun srikaya diduga terjadi karena proses melanisasi pada tubuh A. gossypii.

Menurut Nappi et al. (1992) dalam Dono et al. (2006), menyatakan bahwa dalam proses melanisasi selalu melibatkan polifenol oksidase yang dicirikan oleh warna coklat atau hitam. Senyawa saponin dan tanin yang terkandung dalam ekstrak tepung daun srikaya yang masuk ke dalam tubuh $A$. gossypii akan menghambat pembentukan hormon sehingga keseimbangan hormon 
dalam tubuh terganggu dan tidak dapat melakukan pergantian kulit yang mengakibatkan $A$. gossypii tidak bisa melanjutkan siklus hidupnya.

\section{Lethal Time $50\left(\mathrm{LT}_{50}\right)$}

Hasil sidik ragam menunjukkan bahwa perlakuan beberapa ekstrak tepung daun srikaya menunjukkan pengaruh yang nyata terhadap Lethal Time 50 ( $\left.\mathrm{LT}_{50}\right)$ Aphis gossypii. Hasil rata-rata $\mathrm{LT}_{50}$ setelah dilakukan uji DNMRT 5\% dapat dilihat pada Tabel 2.

Tabel 2 menunjukkan bahwa perlakuan beberapa konsentrasi ekstrak tepung daun srikaya dengan konsentrasi berbeda memberikan pengaruh yang nyata terhadap Lethal Time 50 dengan kisaran kematian $50 \%$ populasi $A$. gossypii yaitu 19,50 jam - 40,50 jam. Perlakuan ekstrak tepung

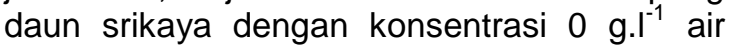

sampai akhir pengamatan (72 jam) tidak mampu menyebabkan kematian 50\% $A$. gossypii, hal ini terjadi karena tidak adanya ekstrak tepung daun srikaya yang diberikan. Perlakuan konsentrasi ekstrak tepung daun srikaya $100 \mathrm{~g} . \mathrm{I}^{-1}$ air, $80 \mathrm{~g} . \mathrm{I}^{-1}$ air, $60 \mathrm{~g} . \mathrm{I}^{-1}$ air, 40

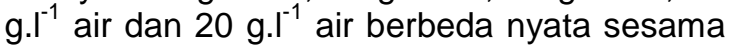
perlakuan lainnya dengan nilai $\mathrm{LT}_{50}$ adalah 19,5 jam, 22 jam, 27 jam, 33,75 jam, dan 40,5 jam.

Hal ini diduga disebabkan karena semakin tinggi konsentrasi ekstrak tepung daun srikaya maka nilai $\mathrm{LT}_{50}$ yang diberikan semakin cepat. Semakin tinggi konsentrasi yang diberikan maka semakin banyak bahan aktif yang terkandung dan semakin cepat serangga uji yang mati. Senyawa toksik yang masuk ke dalam tubuh serangga akan mempengaruhi metabolisme dalam tubuhnya.

Tabel 2. Lethal Time 50 A. gossypii setelah pemberian beberapa konsentrasi ekstrak tepung daun srikaya

\begin{tabular}{cc}
\hline $\begin{array}{c}\text { Konsentrasi ekstrak tepung daun srikaya } \\
\left(\mathrm{g} . \mathrm{I}^{-1} \text { air }\right)\end{array}$ & $\begin{array}{c}\text { Lethal time } 50 \\
\text { (jam) }\end{array}$ \\
\hline 0 & $72,00^{\mathrm{a}}$ \\
20 & $40,50^{\mathrm{b}}$ \\
40 & $33,75^{\mathrm{c}}$ \\
60 & $27,00^{\mathrm{d}}$ \\
80 & $22,00^{\mathrm{e}}$ \\
100 & $19,50^{\dagger}$
\end{tabular}

Keterangan : Angka-angka pada lajur yang diikuti oleh huruf kecil yang tidak sama berbeda nyata menurut uji DNMRT pada taraf $5 \%$ setelah ditransformasikan $\sqrt{ } y+0,5$.

Lu (1994) menyatakan bahwa senyawa yang bersifat racun yang masuk ke tubuh akan mengalami biotransformasi. Proses metabolisme tersebut membutuhkan energi, semakin banyak senyawa racun yang masuk ke tubuh serangga menyebabkan energi yang dibutuhkan untuk proses netralisir semakin besar. Banyaknya energi yang digunakan untuk menetralisir senyawa racun tersebut menyebabkan penghambatan terhadap metabolisme yang lain sehingga serangga akan kekurangan energi dan akhirnya mati.

Perlakuan ekstrak tepung daun srikaya

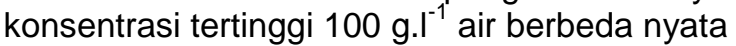
dengan perlakuan lainnya dengan memberikan nilai $\mathrm{LT}_{50}$ tercepat yaitu 19,5 jam. Hal ini disebabkan karena konsentrasi tertinggi menyebabkan senyawa racun dari ekstrak tepung daun srikaya akan semakin tinggi pula sehingga berdampak pada waktu yang dibutuhkan untuk mematikan $50 \%$ A. gossypii menjadi lebih cepat. Hal ini didukung oleh Mulyana (2002) bahwa pemberian konsentrasi yang tinggi menyebabkan serangga cepat mengalami kematian, hal ini disebabkan banyaknya zat aktif yang masuk ke dalam tubuh serangga.

Perlakuan ekstrak tepung daun srikaya

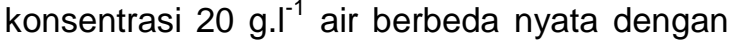
perlakuan lainnya dengan memberikan nilai $\mathrm{LT}_{50}$ terlama yaitu 40,5 jam. Hal ini diduga disebabkan karena pemberian konsentrasi yang rendah, waktu awal kematian dan $\mathrm{LT}_{50}$ yang dibutuhkan dalam mematikan $A$. gossypii juga akan semakin lambat dikarenakan bahan aktif yang terkandung dalam ekstrak tepung daun srikaya tersebut jumlahnya sedikit. Hal ini diperkuat oleh Harbone (1979) dalam Darmayanti (2014) bahwa pemberian konsentrasi ekstrak yang rendah akan menimbulkan pengaruh pada serangga semakin rendah, di samping itu daya kerja suatu pestisida nabati sangat ditentukan oleh besarnya konsentrasi yang diberikan.

\section{Lethal concentrate $\left(\mathrm{LC}_{50 ; 95}\right)$}

Hasil analisis probit menunjukkan bahwa beberapa konsentrasi ekstrak tepung daun srikaya berpengaruh terhadap mortalitas A. gossypii (Tabel 3). 
Tabel 3. Lethal concentration $50\left(\mathrm{LC}_{50}\right)$ dan $95\left(\mathrm{LC}_{90}\right)$ A. gossypii yang diberi perlakuan ekstrak tepung daun srikaya

\begin{tabular}{ccc}
\hline Lethal Concentration (LC) & Konsentrasi (\%) & SK 99\% (\%) \\
\hline LC $_{50}$ & 1,37 & 2,93 \\
LC $_{95}$ & 6,37 & 2,93 \\
\hline
\end{tabular}

Keterangan : SK = Selang Kepercayaan

Tabel 3 menunjukkan bahwa konsentrasi ekstrak tepung daun srikaya yang tepat untuk mematikan $50 \%$ A. gossypii adalah $1,37 \%$ atau setara dengan 13,7 $\mathrm{g.l}^{-1}$ air dengan selang kepercayaan $99 \%$ yaitu 2,93 \%. Konsentrasi ekstrak tepung daun srikaya yang mampu mematikan 95\% $A$. gossypii adalah $6,37 \%$ atau setara dengan $63,7{\mathrm{~g} . \mathrm{I}^{-1}}^{-1}$ air dengan selang kepercayaan 99\% yaitu $2,93 \%$. Konsentrasi ekstrak tepung daun srikaya $1,37 \%$ atau setara dengan $13,7 \mathrm{g.l}^{-1}$ air dapat mematikan hama $50 \%$ A. gossypii mendekati konsentrasi ekstrak tepung daun srikaya di bawah $20 \mathrm{g.l}^{-1}$ air, selanjutnya konsentrasi ekstrak tepung daun srikaya yang dapat mematikan 95\% A. gossypii adalah konsentrasi $6,37 \%$ atau setara dengan 63,7 g..$^{-1}$ air mendekati konsentrasi ekstrak tepung daun srikaya $70 \%$ atau $70{\mathrm{~g} . \mathrm{I}^{-1}}$ air. Menurut Grainge dan Ahmed (1988), menyatakan bahwa efektifitas suatu bahan nabati yang digunakan sebagai insektisida botani sangat tergantung dari bahan yang dipakai.
Sifat bioaktif atau sifat racunnya dari suatu senyawa aktif tergantung pada kondisi tumbuh, umur tanaman dan jenis dari tanaman tersebut. Hal ini sesuai dengan pendapat Prijono (2007), bahwa lethal concentration ekstrak suatu bahan insektisida botani dengan pelarut air efektif jika konsentrasi perlakuan di bawah $10 \%$. Dengan demikian ekstrak tepung daun srikaya efektif dalam mengendalikan $A$. gossypii.

\section{Mortalitas Harian}

Hasil pengamatan mortalitas harian $A$. gossypii dengan perlakuan beberapa konsentrasi ekstrak tepung daun srikaya (Annona squamosa L.) menunjukkan persentase kematian $A$. gossypii mengalami perbedaan tiap 12 jam setelah aplikasi pada tiap konsentrasi dari 24 jam sampai 72 jam setelah aplikasi. Grafik mortalitas harian $A$. gossypii dapat dilihat pada Gambar 2.

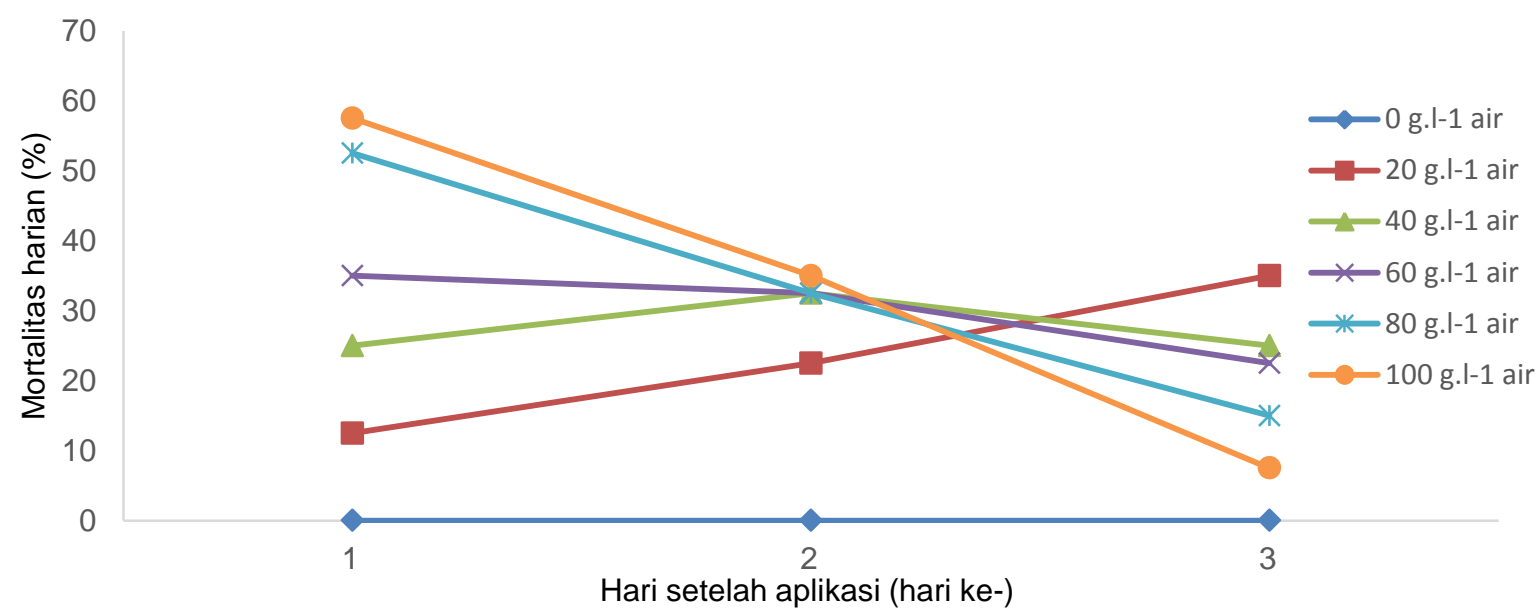

Gambar 2. Mortalitas harian A. gossypii setelah pemberian beberapa konsentrasi ekstrak daun srikaya tiap hari setelah aplikasi

Gambar 2. menunjukkan bahwa pemberian ekstrak tepung daun srikaya mengalami puncak mortalitas pada hari pertama yaitu pada konsentrasi $100 \mathrm{~g}^{\mathrm{I}^{-1}}$ air,

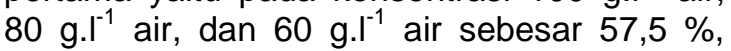
$52,5 \%$, dan $35 \%$. Namun pada konsentrasi

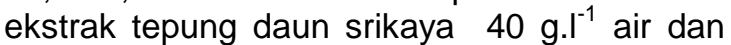
$20{\mathrm{~g} . \mathrm{I}^{-1}}$ air tidak mengalami puncak mortalitas. Pengamatan hari pertama setelah aplikasi ekstrak tepung daun srikaya dengan konsentrasi $100 \mathrm{g.l}^{-1}$ air telah mampu mematikan A. gossypii sebesar 57,5\%.diikuti

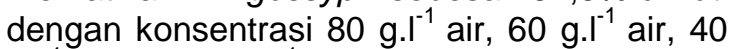

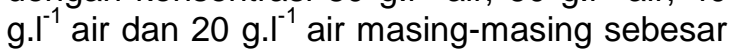
$52,5 \%, 35 \%, 25 \%$ dan $12,5 \%$. Hal ini terjadi karena kandungan senyawa pada konsentrasi yang lebih tinggi aktivitas insektisidanya lebih besar. Semakin tinggi konsentrasi maka semakin banyak yang mati. Pendapat ini diperkuat oleh Yunita et al. (2009) bahwa semakin tinggi konsentrasi senyawa 
insektisida yang digunakan maka tingkat kematian serangga uji semakin tinggi.

Pemberian ekstrak tepung daun srikaya pada hari kedua terjadi penurunan

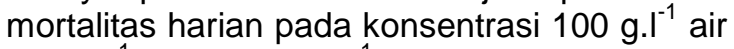

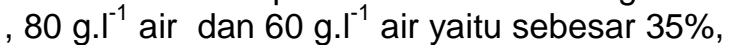
$32,5 \%$, dan $32,5 \%$. Penurunan terjadi diduga karena pestisida nabati pada umumnya akan bekerja secara maksimal pada 24 jam setelah aplikasi (Tukimin dan Rizal, 2002). Selain itu penurunan juga diduga terjadi karena sudah banyaknya $A$. gossypii yang mati pada hari pertama. Pada konsentrasi ekstrak tepung

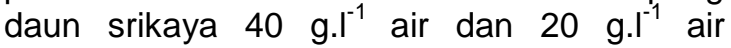
mengalami kenaikan yaitu sebesar $32,5 \%$ dan $22,5 \%$. Hal ini diduga disebabkan karena senyawa squmaosin yang terkandung di dalam ekstrak tepung daun srikaya bekerja dengan maksimal pada hari kedua sehingga menyebabkan terjadinya peningkatan persentase kematian pada A. gossypii.

Pengamatan hari ketiga setelah aplikasi terjadi penurunan mortalitas harian
A. gossypii pada konsentrasi $100 \mathrm{~g}^{-1} \mathrm{I}^{-1}$ air, 80

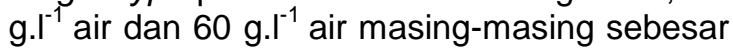
$7,5 \%, 15 \%$, dan $12,5 \%$. \%. Hal ini diduga karena sudah banyaknya hama yang mati pada hari pertama dan kedua. Puncak mortalitas harian $A$. gossypii terjadi pada konsentrasi $20 \mathrm{~g}^{-1} \mathrm{I}^{-1}$ air yaitu sebesar $35 \%$. Hal ini disebabkan konsentrasi rendah sehingga baru mampu mematikan tertinggi pada hari ke 3. Hal ini didukung oleh Tarumingkeng (1992) yang menyatakan bahwa bahan aktif pestisida nabati mampu meracuni hama dan bekerja secara efektif hingga 2-3 hari setelah aplikasi.

\section{Mortalitas Total}

Hasil sidik ragam menunjukkan bahwa perlakuan beberapa konsentrasi ekstrak tepung daun srikaya (Annona squamosa L.) memberikan pengaruh yang nyata terhadap mortalitas total $A$. gossypii. Hasil rata-rata mortalitas total $A$. gossypii setelah dilakukan uji DNMRT pada taraf 5\% dapat dilihat pada Tabel 4.

Tabel 4. Mortalitas total $A$. gossypii setelah pemberian beberapa konsentrasi ekstrak tepung daun srikaya

\begin{tabular}{cc}
\hline Konsentrasi ekstrak tepung daun srikaya $\left(\mathrm{g} \mathrm{I}^{-1}\right.$ air $)$ & $\begin{array}{c}\text { Mortalitas total } \\
(\%)\end{array}$ \\
\hline 0 & $0,0^{\mathrm{a}}$ \\
20 & $70,0^{\mathrm{c}}$ \\
40 & $82,5^{\mathrm{b}}$ \\
60 & $90,0^{\mathrm{b}}$ \\
80 & $100,0^{\mathrm{a}}$ \\
100 & $100,0^{\mathrm{a}}$ \\
\hline
\end{tabular}

Keterangan : Angka-angka pada lajur yang diikuti oleh huruf kecil yang tidak sama berbeda nyata menurut uji DNMRT pada taraf $5 \%$ setelah ditransformasikan $\sqrt{ } y+0,5$.

Tabel 4 menunjukkan bahwa berbagai konsentrasi ekstrak tepung daun srikaya berbeda nyata terhadap mortalitas total $A$. gossypii. Perlakuan konsentrasi ekstrak tepung daun srikaya $20 \mathrm{~g} . \mathrm{I}^{-1}$ air mortalitas $A$. gossypii sebesar $70 \%$ dan berbeda nyata dengan perlakuan lainnya. Perlakuan konsentrasi ekstrak tepung daun srikaya 40 g. $\mathrm{I}^{-1}$ air dengan mortalitas total yaitu $82,5 \%$, berbeda tidak nyata dengan perlakuan $60 \mathrm{~g}^{-1} \mathrm{I}^{-1}$ air dengan mortalitas total $90 \%$ namun berbeda nyata dengan perlakuan lainnya. Perlakuan konsentrasi ekstrak tepung daun

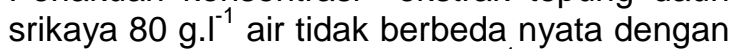
perlakuan konsentrasi $100 \mathrm{~g}^{-1}{ }^{-1}$ air ekstrak tepung daun srikaya dengan mortalitas total sebesar $100 \%$, namun berbeda nyata dengan perlakuan lainnya. Hal ini diduga bahwa semakin tinggi konsentrasi yang digunakan maka semakin banyak senyawa squamosin yang terkandung sehingga menyebabkan mortalitas total A. gossypii semakin besar. Ardiansyah et al. (2001) menyatakan bahwa semakin tinggi konsentrasi yang diberikan, maka semakin tinggi pula kandungan senyawa insektisida sehingga mempercepat proses kematian hama.

Perlakuan ekstrak tepung daun

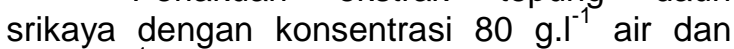
$100 \mathrm{g.l}^{-1}$ air menyebabkan mortalitas total tertinggi yaitu $100 \%$ berbeda nyata dengan perlakuan lainnya. Hal ini sesuai dengan pernyataan Mulyana (2002) bahwa pemberian konsentrasi yang tinggi menyebabkan serangga cepat mengalami kematian, hal ini disebabkan banyaknya zat aktif yang masuk ke dalam tubuh serangga.

Perlakuan ekstrak tepung daun srikaya dengan konsentrasi $40 \mathrm{~g}^{-1} \mathrm{l}^{-1}$ air berbeda nyata dengan perlakuan $20 \mathrm{~g} . \mathrm{I}^{-1}$ air dengan mortalitas total $82,5 \%$, dan $70 \%$. Peningkatan konsentrasi ekstrak tepung daun srikaya akan meningkatkan mortalitas $A$. gossypii. Dewi (2010) menyatakan bahwa daya racun yang terkandung dalam insektisida botani akan semakin meningkat jika 
konsentrasi yang digunakan semakin tinggi sehingga proses fisiologis terganggu dan perkembangan serangga terhambat.

Perlakuan ekstrak tepung daun srikaya dengan konsentrasi 60 g..$^{-1}$ air tidak berbeda nyata dengan perlakuan $40 \mathrm{~g}^{-1} \mathrm{I}^{-1}$ air dengan mortalitas total $90 \%$, dan $82,5 \%$. Hal ini diduga $A$. gossypii masih mampu mentolerir senyawa aktif dari ekstrak tepung daun srikaya sehingga dengan peningkatan konsentrasi yang digunakan tidak menimbulkan pengaruh yang nyata dalam mematikan A. gossypii.

Srikaya mengandung senyawa squamosin yang bersifat insektisida. Senyawa squamosin sebagai racun kontak, yang masuk melalui kulit (kutikula) dan ditransportasikan ke bagian tubuh serangga tempat pestisida aktif bekerja, setelah masuk ke dalam tubuh hama akan bekerja sebagai racun saraf dengan menghambat kerja enzim asetilkolinesterase, Windasari et. al (2012) menyatakan bahwa jika kerja dari enzim asetikolinesterase terhambat akan terjadi penumpukan asetilkolin yang dibentuk oleh sistem saraf putat untuk menghantarkan impuls dari sel saraf ke sel otot, sehingga menyebabkan kekacauan pada sistem penghantar impuls ke otot sehingga mengakibatkan otot kejang, terjadi kelumpuhan dan berakhir kematian.

Ekstrak tepung daun srikaya dengan konsentrasi $40 \mathrm{g.I}^{-1}$ air efektif mengendalikan A. gossypii menyebabkan mortalitas mencapai $82,5 \%$. Hal ini sesuai dengan pernyataan Dadang dan Prijono (2008) bahwa insektisida dikatakan efektif apabila mampu mematikan serangga hama sama atau lebih dari $80 \%$.

\section{KESIMPULAN DAN SARAN}

\section{Kesimpulan}

Hasil penelitian penggunaan ekstrak tepung daun srikaya (Annona squamosa L.) mengendalikan hama $A$. gossypii pada tanaman cabai dapat diperoleh kesimpulan sebagai berikut:

1. Aplikasi ekstrak tepung daun srikaya (Annona aquamosa L.) pada konsentrasi $40 \mathrm{~g}^{-l^{-1}}$ air sudah efektif mengendalikan hama $A$. gossypii dengan mortalitas total sebesar 82,5\%, awal kematian 6,75 jam dan Lethal time 50 (LT 50 ) 33,75 jam.

2. Konsentrasi yang tepat untuk mematikan $50 \%$ hama $A$. gossypii adalah $1,37 \%$ atau setara dengan 13,7 g. I $^{-1}$ air ekstrak daun srikaya, sementara itu konsentrasi yang mampu untuk mematikan 95\% hama $A$. gossypii adalah $6,73 \%$ atau setara dengan 67,3 g.l I $^{-1}$ air ekstrak daun srikaya.

\section{Saran}

Sebaiknya untuk mengendalikan hama A. gossypii pada tanaman cabai menggunakan konsentrasi ekstrak tepung daun srikaya $40 \mathrm{~g} . \mathrm{l}^{-}$ ${ }^{1}$ air.

\section{DAFTAR PUSTAKA}

Ardiansyah. 2001. Toksisitas ekstrak daun mimba (Azadirachta indica A. Juss) pada siput murbei (Pamoceae canaliculata). Skripsi Universitas Negeri Surakarta. (Tidak dipublikasikan)

Badan Pusat Statistik Riau. 2018. Riau dalam Angka 201. Pekanbaru.

Dadang dan D. Prijono. 2008. Insektisida Nabati Prinsip, Pemanfaatan dan Pengembangan. Departemen Proteksi Tanaman Institut Pertanian Bogor. Bogor.

Darmayanti, I. 2014. Uji Beberapa Konsentrasi Ekstrak Daun Sirih Hutan (Piper aduncum L.) untuk Mengendalikan Hama Ulat Grayak (Spodoptera litura F.) (Lepidoptera:Noctuidae) pada Tanaman Kedelai. Skripsi (Tidak dipublikasikan). Fakultas Pertanian Universitas Riau. Pekanbaru.

Departemen Pertanian. 1989. Upaya Peningkatan Produksi Kedelai. Balai Informasi Pertanian Sumatra Utara. Medan.

Dewi, R. S. 2010. Keefektifan Tiga Jenis Tumbuhan terhadap Paracoccus marginatus dan Tetraychus sp. pada Tanaman Jarak Pagar (Jatropha curcas L). Tesis (Tidak dipublikasikan). Institut Pertanian Bogor. Bogor.

Dono, D., D. Prijono, S. Manuwoto, D. Buchori, Dadang dan Hasim. 2006. Pengaruh rokaglamida dan parasitoid Eriborus argentiopelosus terhadap kadar profil protein hemolimfa larva Crocidolomia pavonana serta melanisasi kutikula. Jurnal Agrikultur. 17(3): 185-194.

Grainge dan K. Ahmed. 1988. Penetapan LC 50 Ekstrak Pucuk Daun Kepayang (Pangium edule Rein W.) terhadap Ulat Pemakan Daun Kubis (Plutella xylostella Linn.). Skripsi (Tidak dipublikasikan). Universitas Lampung. Lampung.

Herlinda, S., T. Irwanto, T. Adam, dan T. Irsan. 2009. Perkembangan populasi Aphis 
gossypii Glover (Homoptera: Aphididae) dan kumbang lembing pada tanaman cabai merah dan rawit di Inderalaya. Seminar Nasional Perlindungan Tanaman, Bogor 5-6 Agustus 2009. Lembaga Penelitian Universitas Sriwijaya.

Kardinan, A. 2002. Pestisida Nabati: Ramuan dan Aplikasi. Penebar Swadaya. Jakarta

Lu, F. C. 1994. Toksikologi Dasar. Edisi Kedua. Universitas Indonesia Press. Jakarta.

Martono, B. E. 2004. Plasma nutfah insektisida nabati. Jurnal Pengembangan Teknologi TRO. XVI (1): 43-59.

Mulyana. 2002. Ekstraksi Senyawa Aktif Alkaloid, Kuinon dan Saponin dari Tumbuhan Kecubung sebagai Larvasida dan Insektisida terhadap Nyamuk Aedes aegepty. Skripsi (Tidak dipublikasikan). Institut Pertanian Bogor. Bogor.

Novizan. 2002. Membuat dan Memanfaatkan Pestisida Ramah Lingkungan. Agromedia Pustaka Jakarta.

Nursal, E., P. S. Sudharto dan R. Desmier de Chenon. 1997. Pengaruh Konsentrasi Ekstrak Bahan Pestisida Nabati Terhadap Hama. Balai Penelitian Tanaman Obat Bogor. Bogor.

Pracaya. 2007. Hama dan Penyakit Tumbuhan. Penebar Swadaya. Jakarta.

Prijono, D. 2007. Modul Praktikum Toksikologi Insektisida Pengujian Toksisitas Insektisida. Departemen Proteksi Tanaman. IPB. Bogor.

Sinaga, Nelly M. R., 2010, Pengendalian Callosobruchus chinensis (Coleoptera : Bruchidae) dengan Menggunakan Serbuk dan Ekstrak Biji Sirsak, Saga dan Bengkuang pada Benih Kacang Hijau. Universitas Sumatera Utara. Medan.

Tarumingkeng, R. C. 1992. Insektisida: Sifat, Mekanisme Kerja dan Dampak Penggunaanya. Universitas Kristen Krida Wacana. Jakarta.

Tukimin dan M. Rizal. 2002. Pengaruh Ekstrak Daun Gamal (Gliricidia sepium) terhadap Mortalitas Kutu Daun Kapas Aphis gossypii Glover. Balittas. Malang.

Windasari, Novita. B. Prijono dan N. Kariada. 2012. Toksisitas ekstrak biji srikaya dan pengaruhnya terhadap viabilitas rayap kayu kering. Unnes Journal of life science. 1(1): 1-7

Yunita, E., H. S. Nanik dan W. H. Jafron. 2009. Pengaruh ekstrak daun tekelan (Eupatorium riparium) terhadap mortalitas dan perkembangan larva Spodoptera litura. Jurnal Bioma. 11(1): 5-6

Zarkani, A. 2008. Aktivitas Insektisida Ekstrak Piper retrofractum Vahl. dan Tephrosea vogeii Hook. F. terhadap Crocidolomia pavonana (F) dan Plutella xylostella (L) serta Keamanan Ekstrak tersebut terhadap Diadegma semiclausum (Hellen). Tesis (Tidak dipublikasikan). Institut Pertanian Bogor. Bogor. 